\title{
Research on Library and Information Science in Spain: diagnosis 2020
}

\author{
Ernest Abadal; Javier Guallar
}

Nota: Este artículo se puede leer en español en:

http://www.elprofesionaldelainformacion.com/contenidos/2020/jul/abadal-guallar_es.pdf

How to cite this article:

Abadal, Ernest; Guallar, Javier (2020). "Research on Library and Information Science in Spain: diagnosis 2020".

Profesional de la información, v. 29, n. 4, e290444.

https://doi.org/10.3145/epi.2020.jul.44

Invited article received on 23-07-2020

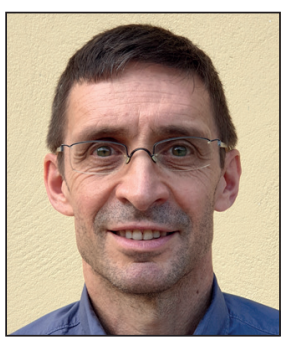

\author{
Ernest Abadal \\ https://orcid.org/0000-0002-9151-6437 \\ Universitat de Barcelona \\ Centre de Recerca en Inf., Com. i Cultura \\ Fac. d'Informació y Mitjans Audiovisuals \\ Melcior de Palau, 140 \\ 08014 Barcelona, Spain \\ abadal@ub.edu
}

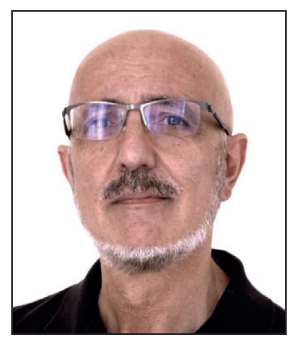

Javier Guallar

https://orcid.org/0000-0002-8601-3990

Universitat de Barcelona

Centre de Recerca en Inf., Com. i Cultura

Fac. d'Informació y Mitjans Audiovisuals

Melcior de Palau, 140

08014 Barcelona, Spain

jguallar@ub.edu

\begin{abstract}
Spanish research in Documentation (or Library and Information Science, LIS) rose to prominence in the 1980s, in parallel with the creation of university programmes in LIS, and activity in this field continued to increase significantly until the year 2000. During this period, research in Documentation was oriented towards dissemination rather than innovation, its international impact was low, and it suffered from limited financial and human resources and a lack of methodological quality. In the first 20 years of the 21st century, research in this field has experienced an extraordinary level of growth and diversification, with the result that many of the problems mentioned above have been resolved. This article presents a general overview of Documentation research in Spain over the last 20 years based on an analysis of five fundamental aspects: publications (articles and monographs), topics and methodologies, scientific journals, research projects, and doctoral theses. General descriptive data from public statistical sources are offered on each of these aspects, together with observations drawn from a bibliographic review. Our conclusion is that the evolution of Spanish research in Documentation over the last 20 years has been very positive, due to a quantitative increase in activity (publications, theses, research projects, etc.) and a qualitative improvement in the use of research methods and techniques, as well as a diversification of research topics. However, there is room for improvement in the area of internationalisation (collaboration with foreign authors) and the presentation of international projects. There is also a risk that retirement of researchers and the absence of generational renewal of staff, especially at universities, may slow down this growth.
\end{abstract}

\section{Keywords}

Research; Documentation; Library and Information Science; LIS; Scholarly communication; Papers; Articles; Academic journals; Doctoral theses; Research projects; Research topics; Research methodologies; Spain.

\section{Funding}

This study has been conducted in the context of the consolidated research group "Cultura i continguts digitals" (SGR 2017-422), funded by Agència de Gestió d'Ajuts Universitaris i de Recerca (Agaur) of the Generalitat de Catalunya.

\section{Introduction}

Documentation (which is used in this article interchangeably with Library and Information Science, or LIS) is an academic discipline established and consolidated on the basis of the work of information professionals in libraries, archives, and documentation centres. The activity of these professionals has also constituted the starting point for the work of researchers in Documentation, who use methodologies drawn mainly from the social sciences, and who have progressively expanded their lines of research from the study of libraries to include objects (documents, information), processes (selection, cataloguing, classification, retrieval, dissemination, etc.) and users, among other topics. 
One of the first international studies to evaluate the state of research in Library and Information Science was "The place of research in library service" (Williamson, 1931), published in The library quarterly, the first academic journal dedicated to this field. Williamson's article described the issues in research in the United States at that time: based on individual work, and affected by a lack of planning, financial resources, and specialised journals for the dissemination of research results. Eighty years later, Larivière, Sugimoto \& Cronin (2012) reviewed more than a century's history of Documentation as an academic discipline, based on a bibliometric study of 96,000 articles in 160 Documentation journals in the period from 1900 to 2010 . The result was a complete bibliographical review of these types of studies that provided clear evidence of the growth of the discipline (in terms of the number of articles, journals, and authors), the rise of academic collaboration (with a marked increase in the number of authors per article since 1990), the increased visibility of Documentation (the average number of citations per article is higher than it is for social sciences), and a high degree of permeability (authors also publish in other disciplines and are frequently cited in fields outside Documentation).

Focusing on the case of Spain, it seems clear that research activity in this field first rose to prominence in the 1980s (Delgado-López-Cózar, 2000), in parallel with the creation of schools of library and information science at universities and the introduction of degree programmes at every level (bachelor's, master's, and especially doctoral degrees) (Abadal, 2013). Although there is no bibliometric study on Spain as exhaustive as the review by Larivière, Sugimoto \& Cronin (2012), there are two metrics that indicate the level of development of research

(Abadal, 1994; Delgado-López-Cózar, 2000), which can serve to characterise the last two decades of the $20^{\text {th }}$ century (1980-2000).

Based on an analysis of scientific production (monographs, theses, projects, etc.) in Documentation for the period 19751992, Abadal (1994) highlighted three characteristics of Spanish research:

- oriented towards dissemination (very little original research, very little innovation);

- low international impact (very few authors publishing in international journals); and

- lack of financial and human resources.

A few years later, based on a comprehensive bibliographical review, Delgado-López-Cózar (2000) assessed research conducted in the period 1976-1996, classifying it as being at an "embryonic stage". This author highlighted the marked growth of publications in LIS (articles, monographs, theses, etc.), but considered that research was still in a start-up phase and suffered particularly from a lack of methodological quality and from insubstantial research methods. Nevertheless, he was optimistic and considered that the future of research in LIS was promising, with plenty of opportunities.

In the first 20 years of the new millennium, the opportunities that Delgado-López-Cózar foresaw have clearly been seized upon, as there has been a notable increase in research activity. The diversity and dynamism of the field has been reflected in an increased number of publications, improved research quality, a diversification of topics, etc. Although this diversification increases the complexity and difficulties associated with conducting comprehensive reviews like the ones described above, we seek to offer the clearest diagnosis possible here. To this end, we have selected five areas that will serve collectively as a barometer to evaluate the degree of progress of research in Documentation over the last twenty years. These areas are:

- publications (articles and monographs)

- topics and methodologies

- academic journals

- research projects

- doctoral theses

It is also worth noting that this monograph issue of Profesional de la información features articles focusing on each of these lines of study, representing particular relevant complementary contributions to this diagnostic.

Our objective here is to present a general overview of research in Documentation over the last 20 years, based on descriptive data and on a bibliographical review of the most representative studies in terms of the five aspects indicated above (publications, topics, journals, projects, and theses). In this way, we will gather the evidence needed to be able to compare them with the previous diagnoses by Abadal and Delgado-López-Cózar and to confirm or refute the limitations they identify.

\section{Publications}

Articles by Spanish authors have been published in various ways, predominantly in journals, but also with a notable production of monographs. What follows is a review of the evolution of article and monograph publications based on data from Clarivate InCites and also from a bibliographical review of recent studies on both types of publications. 
InCites offers exact data on the presence of journal articles by Spanish authors in WoS for the period 1980-2020. To obtain this data, we entered the following parameters: period: "1980-2020"; topic: "Information \& Library Science"; authors affiliated with Spanish organisations; and type of document: "article".

Table 1 and Figure 1 clearly reveal the quantitative leap that has occurred since the year 2000. That leap is irrefutably dramatic, as production of indexed articles has increased by 18 times. Moreover, the total number is higher in absolute terms than those currently found in other areas of the social sciences such as Communication (3,142 articles), Anthropology $(3,178)$, and Sociology $(2,825)$.

Tabla 1. Articles by Spanish authors in WoS

\begin{tabular}{|l|c|c|c|}
\cline { 2 - 4 } \multicolumn{1}{c|}{} & WoS & \% of articles cited & \% international collaboration \\
\hline $1980-2000$ & 179 & 82.0 & 14.5 \\
\hline $2001-2020$ & 4,014 & 72.0 & 26.1 \\
\hline Total (1980-2020) & 4,193 & 72.4 & 25.7 \\
\hline
\end{tabular}

Source: Clarivate InCites

Although it is true that the journals Profesional de la información (EPI) (1,099 articles) and Revista española de documentación cientifica (REDC) (363 articles) were added to WoS in 2006 and 2008, respectively, and that this reinforced the exponential growth in the number of publications, it is not a determining factor because the total number of published articles is markedly higher than the totals contributed by these two journals (even if we also include the Mexican journal Investigación bibliotecológica, with 130 articles).

Numerous descriptive studies have been published on article production. We will refer here only to those that have used international databases as data sources. Jiménez-Contreras (2002) studied production by Spanish authors in WoS for the period 1992-2001 and subsequently expanded his study to 1995-2004 (Jiménez-Contreras; Delgado-López-Cózar; Ruiz-Pérez, 2006). The SCImago group $(2005,2006)$ conducted a similar study covering this same period. At that time, however, the dataset was made up of fewer than 250 publications. More recently, Olmeda-Gómez \& De-Moya-Anegón (2016) expanded the focus to analyse some 13,000 articles indexed in Scopus from journals in the "Library and Information Science" category between 2003 and 2012. The original aspect of this study lies in the fact that it placed the Spanish contribution in an international context, confirming that Spain was the second biggest producer of publications in the period studied in Europe (after the United Kingdom) and that it had the highest growth rate.

Trend Graph

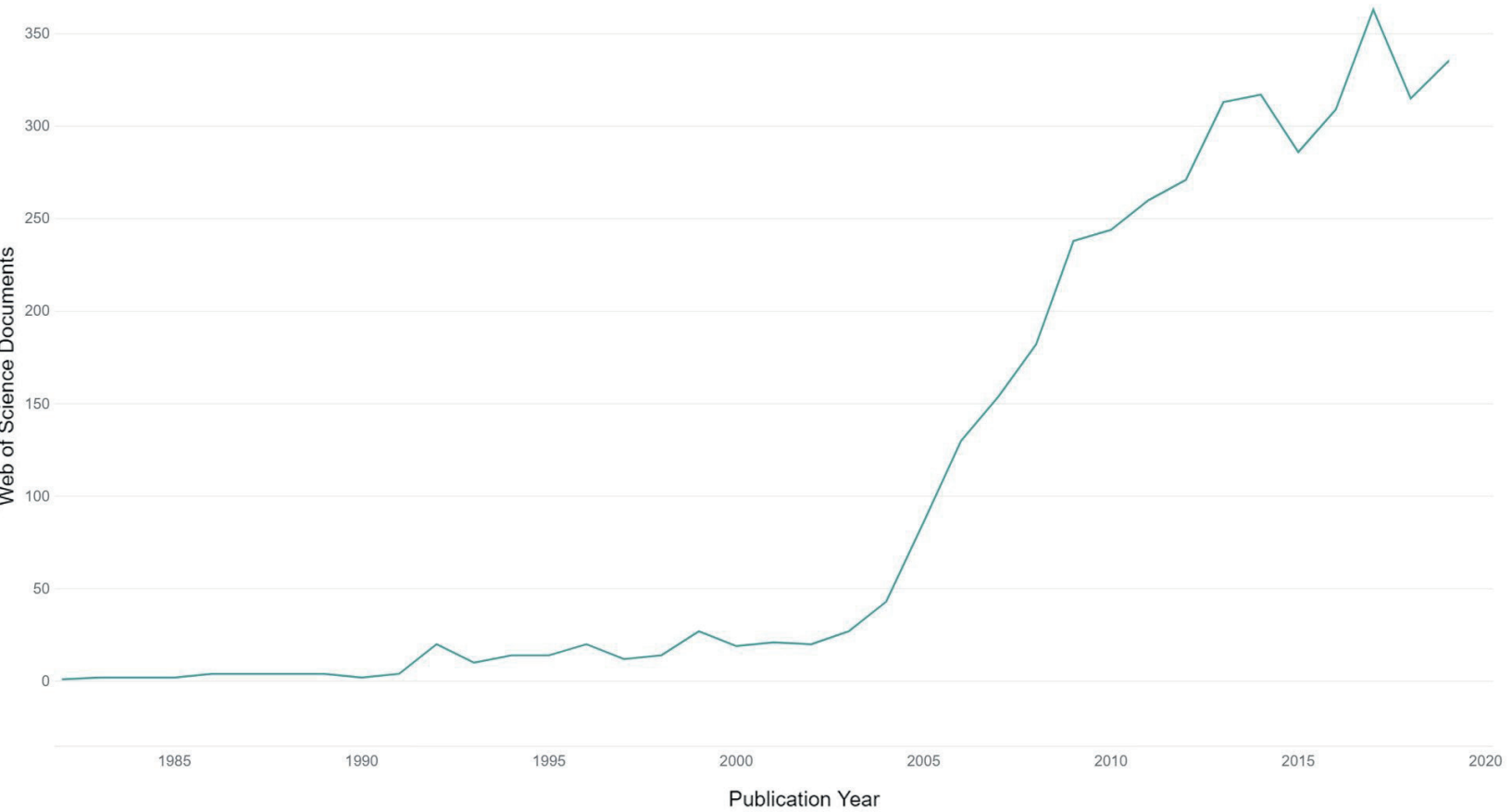

- INFORMATION SCIENCE \& LIBRARY SCIENCE

Indicators: Web of Science documents. Schema: web of science. Research Area: information science \& library science. Location: spain. Document type: article. Dataset: InCites Dataset. InCites dataset updated Jul 10, 2020. Includes Web of Science content indexed through May 31, 2020. Export Date: Jul 20, 2020.

Figure 1. Articles by Spanish authors in LIS journals in WoS (1980-2020).

Source: Clarivate InCites 
There are various studies available dealing with academic collaborations by Spanish authors in the field of Documentation. Ardanuy (2012) based his study on 909 articles published in WoS between 1967 and 2009, analysing a range of aspects of collaboration (number of authors, institutions involved, international scope, etc.). A more extensive analysis that included LIS authors from France, Germany, Spain, and the United Kingdom (Urbano; Ardanuy, 2020), based on 8,537 publications indexed in Scopus for the period 2010-2017, found a low level of interdisciplinary collaboration, as only $7.7 \%$ of articles published in Documentation journals were written by LIS scholars in collaboration with authors from other disciplines (Communications, Economics, Information Technology, etc.).

The proportion of international collaborations also constitutes an important indicator. Table 1 shows the percentage of articles that have been written in collaboration with authors from other countries, which has also seen a marked increase, from $10.8 \%$ to $26.5 \%$. Ardanuy (2012) placed international collaboration at $9.9 \%$ of total articles for the period 1967-2009. The study by Ferran-Ferrer et al. (2017), however, found international collaboration among Spanish authors to be only 5.7\% (although it is important to note that this study limited its analysis to Spanish journals).

Another point of note is that there are very few studies of article production that analyse gender. In fact, there is not a single specific study on the question, although we do know that $40 \%$ of authors of WoS publications were women and that their level of collaboration was lower than that of men (Ardanuy, 2012), while female authors in the Spanish journals indexed in Scopus represented $45.5 \%$ of the total (Ferran-Ferrer et al., 2017).

Studies of publications by Spanish authors concerned exclusively with descriptive aspects (e.g. identifying the most productive and frequently cited authors, institutions, and journals in a country) have fallen into disuse due to the fact that the current features of the WoS database make it possible to obtain this information with the mere press of a button, without the need to download or process bibliographical records.

Studies of monographs, on the other hand, are quite rare, and in fact none have been published recently. However, we can chart the increase in the number of published monographs by means of a bibliographical review. Thus, in the period 1940-1992 a total of 113 monographs specialising in LIS were published, the main publishers being Fuinca, Mitre, Consorci d'Informació i Documentació de Catalunya and Paraninfo (Abadal, 1994, p. 92). A more recent study (Fuentes-Pujol; González-Quesada, 2001) identified 320 monographs published between 1980 and 1999, with the most prominent publishers being Síntesis, Pirámide, Paraninfo, and Trea. These authors point out that a significant proportion of titles are manuals and that there was a low level of specialisation. Finally, in the last study of this type, Pons (1998) located around 1,600 monographs on Library and Information Science published in Spain in the period from 1990 to 1995 . In this case, however, foreign authors were also included and the selection criteria were slightly broader than those of the two earlier studies.

Since then, there have been no further studies of published monographs, mainly due to the difficulty associated with data collection. In contrast with articles, there are no monograph databases that would facilitate a detailed topic-based analysis, which explains the limited number of studies that have been done.

One other source worthy of mention is the SPI (Scholarly Publishers Indicators) database, which offers indicators to evaluate monograph collections in the Humanities and Social Sciences, which has been developed by the ILIA group at the Spanish National Research Council (CSIC). However, this database does not allow the identification of production by country.

\section{Research topics and methods}

One of the first bibliographical reviews of studies related to research topics and methods used in Documentation was by Delgado-López-Cózar (2002), which analysed around 50 studies with an international (and also national) scope from the 1970 s to the 1990s (with the bulk of the studies from the 1980s). In the current issue of this journal, Tramullas (2020) has adopted a similar model to update the earlier studies, with a systematic review of 32 international studies published between 2000 and 2019 that analyse the research topics, methods, and techniques used in Documentation.

In Spain, various studies on research topics and methods have been published that offer an overview of the situation over the past twenty years:

\section{Topics}

Research topics have been analysed with different classifications or taxonomies and in relation to different types and sets of publications, producing results which, due to their diversity, are somewhat difficult to compare. Any comparative analysis should therefore be conducted with caution.
If there is a single major topic in LIS that arouses widespread interest for its dynamism, it is the area of informetrics and bibliometrics 
First of all, with respect to the topic categories used, there are studies based either on elaborate classifications taken from pre-existing indexing instruments or languages or on taxonomies created by the authors of the research themselves in accordance with the results obtained. Falling into the first group are studies by Kawalec (2013) and Travieso-Rodríguez \& Ríos-Hilario (2020), which adopt the JITA (Classification Schema of Library and Information Science), a topic classification system established by the e-LIS repository; and research by Ferran-Ferrer et al. (2017), Guallar et al. (2017), and González-Alcaide \& González-Teruel (2020) which are based on the Tesauro de Biblioteconomía y Documentación created by CSIC. The second group includes research dating back to the beginning of the period analysed, such as the studies by Delgado-López-Cózar (2000; 2002) based on the classification developed by Järvelin \& Vakkari (1990; 1993), as well as more recent studies by Olmeda-Gómez, Ovalle-Perandones \& Perianes-Rodríguez (2017), and García-Marco, Figuerola \& Pinto 2020) based on a previous international study (Figuerola; García-Marco; Pinto, 2017) and by López-Robles et al. (2019) about the journal Profesional de la información. In all the studies in this second group, the authors concerned use co-word analysis, topic modelling, and science mapping techniques, respectively, to establish a series of topic areas and sub-areas.

The types of documents analysed to research the topics are mostly articles from Spanish journals, compiled using databases such as Web of Science (Olmeda-Gómez; Ovalle-Perandones; Perianes-Rodríguez, 2017), Scopus (Ferran-Ferrer et al., 2017) and LISA (García-Marco; Figuerola; Pinto, 2020). But there are also studies of other document sources such as research projects (Travieso-Rodríguez; Ríos-Hilario, 2020) and doctoral theses (González-Alcaide; González-Teruel, 2020), in such cases involving document sets compiled ad hoc by the researchers.

The results of all these studies make it possible to sketch a general picture of the research topics chosen. In his overview of 20 years of international research, Tramullas (2020) points out that there is no clear consensus on the key topics of the discipline because they are in a constant state of dynamic change. If there is a single major topic in LIS that arouses widespread interest for its dynamism, it is the area of informetrics and bibliometrics, which can be broken down into various sub-areas: for example, Olmeda-Gómez, Ovalle-Perandones \& Perianes-Rodríguez (2017) highlight four lines of research within this area (bibliometric analysis, co-authorship, citation analysis, and cybermetrics) and García-Marco, Figuerola \& Pinto (2020) point to four sub-areas (methodologies and techniques, citation and impact studies, research evaluation and applied interdisciplinary informetrics). Other topic areas that are clearly highlighted in some studies include information sources, which is the most productive area in the studies by Kawalec (2013) and by Ferran-Ferrer et al. (2017), in the latter case on a par with the aforementioned area of informetrics and bibliometrics. Research more directly related to the library and documentation profession seems to have been less significant in recent years, although such research continues to appear in studies. Finally, all these observations need to be qualified with the acknowledgement that in some areas like health documentation and informetrics, there has been an increase in publications by Spanish researchers in non-Spanish international journals, the data on which is not included here.

In short, given that all these studies have adopted different methodologies, it will continue to be difficult to make comparisons or to map the evolution of the main lines of research in Documentation.

\section{Research methods}

In Spain, studies of research methods in Documentation have a clear benchmark in the aforementioned study by Delgado López-Cózar (2002); however, there have not been many such studies in the last two decades, leaving us without the kind of detailed view we have on the question of topics. There are a few that can be highlighted, such as the studies by Ríos-Hilario (2001) and

Research methods are characterised by the predominant role given to descriptive research, the significant use of metric and theoretical methods and the absence of experimental research

Ríos-Hilario \& Travieso-Rodríguez (2013) on the journal REDC, by Guallar (2003) on news documentation, and in more recent years, the two studies by the group of authors Ferran-Ferrer, Guallar, Abadal \& Server on articles in Spanish journals included in Scopus from 2012 to 2014 (Ferran-Ferrer et al. 2017; Guallar et al. 2017), and by Faba-Pérez \& PérezPulido (2019) based on Spanish doctoral theses in the period 2008-2018.

As was the case with topics, there is no consensus on the classification and characterisation of research techniques and methods. As Tramullas notes in his international review in this monograph,

"what for some researchers can be a method, for others can be a technique that can be applied within one or more methodological frameworks" (Tramullas, 2020).

This author highlights the fact that researchers do not always make a clear distinction in their studies between methods and techniques, a fact that poses difficulties for any meta-analysis of this question.

If we consider the most recent studies available, Ferran-Ferrer et al. (2017) and Guallar et al. (2017) adopt a classification of methods and techniques previously proposed by Abadal (2006) to obtain results that reveal a balance between quantitative and qualitative research, finding descriptive research to be the most common method, followed by bibliometrics and cybermetrics, and theoretical and evaluative research, while content analysis, text interpretation, citation or link analysis, and surveys are the most commonly used techniques. Conversely, experimental and bibliographical 
research is very rarely used, as are discussion group techniques, observation, the Delphi method, and experiments. Faba-Pérez \& Pérez-Pulido (2019) obtain very similar results, with the exception that the bibliographical method appears among the most frequently used (specifically, in second place behind the descriptive method).

In short, despite their limited number, studies of research methods reveal some apparently clear tendencies, such as the predominant role of descriptive research, the significant use of metric and theoretical methods and the absence of experimental research.

\section{Academic journals}

The MIAR database, created and maintained by Universitat de Barcelona, is a prominent source for information on international academic journals, especially in human and social sciences (Rodríguez-Gairín; Somoza-Fernández; Urbano, 2011). According to data from this source, there are 44 academic journals specialising in Information and Documentation. However, some of these journals are no longer in print and others are not actually academic, reducing the total to 18 titles, shown in Table 2.

Journal mergers and co-editions need to be studied to ensure a higher number of original studies and more resources (both financial and human) that would help enhance professionalisation and features

Table 2. Active Spanish LIS journals

\begin{tabular}{|c|c|c|c|}
\hline Title & Publisher & Creation & Indexing \\
\hline Anales de documentación $(A D)$ & Universidad de Murcia & 1998 & Scopus, ESCI \\
\hline Anuario ThinkEPI & Ediciones Profesionales de la Información SL & 2007 & \\
\hline BiD: textos universitaris de biblioteconomia i documentació & $\begin{array}{l}\text { Universitat de Barcelona } \\
\text { y Universitat Oberta de Catalunya }\end{array}$ & 1998 & Scopus, ESCl \\
\hline Boletín de la Anabad & $\begin{array}{l}\text { Federación Española de Asociaciones de Archiveros, Bi- } \\
\text { bliotecarios, Arqueólogos, Museólogos y Documentalistas }\end{array}$ & 1950 & \\
\hline Boletín de la Asociación Andaluza de Bibliotecarios & Asociación Andaluza de Bibliotecarios & 1984 & \\
\hline Cuadernos de documentación multimedia & Universidad Complutense & 1992 & ESCl \\
\hline Documentación de las ciencias de la información & Universidad Complutense & 1976 & ESCl \\
\hline Hipertext.net & Universitat Pompeu Fabra & 2002 & \\
\hline Ibersid & Universidad de Zaragoza & 2007 & Scopus, ESCl \\
\hline Item: revista de biblioteconomia i documentació & $\begin{array}{l}\text { Col-legi Oficial de Bibliotecaris-Documentalistes de } \\
\text { Catalunya }\end{array}$ & 1975 & \\
\hline Lligall. Revista catalana d'arxivística & Associació d'Arxivers de Catalunya-Gestors Documentals & 1988 & \\
\hline Métodos de información & $\begin{array}{l}\text { Col-legi Oficial de Bibliotecaris-Documentalistes de la } \\
\text { Comunitat Valenciana }\end{array}$ & 1994 & ESCl \\
\hline Profesional de la información & Ediciones Profesionales de la Información SL & 1992 & Scopus, SSCI \\
\hline Revista española de documentación científica & Consejo Superior de Investigaciones Científicas & 1977 & Scopus, SSCI \\
\hline Revista general de información y documentación & Universidad Complutense de Madrid & 1991 & Scopus, ESCI \\
\hline Scire & Universidad de Zaragoza & 1995 & Scopus, ESCI \\
\hline Tabula: revista de archivos de Castilla y León & Asociación de Archiveros de Castilla y León & 1992 & \\
\hline Tria & Asociación de Archiveros de Andalucía & 1994 & \\
\hline
\end{tabular}

Source: MIAR and Abadal, 2018.

All of these journals have publishers operated either by academic institutions (various universities and the CSIC) or professional associations (Cobdc, Cobdcv, etc.), while only two of them have a private publisher (Ediciones Profesionales de la Información SL). The vast majority (15) have foundation dates prior to the year 2000, while only three were established in the decade 2000-2010. No new academic journal has been founded since 2007 (the year of foundation of Ibersid and Anuario ThinkEPI). This is also confirmed in the study by Urbano et al. (2020), which focuses on a total of 62 international Information and Documentation journals that started up or changed their titles in the period 2013-2018 (none of which is Spanish). The analysis reveals that most of them are open access academic journals that publish only a few articles a year, have a minimal presence on databases, and are rarely cited.

The most remarkable change in the last twenty years has without doubt been the notable international recognition and visibility achieved by ten of these journals. The two most significant titles are the aforementioned EPI and REDC, which 
are indexed in the WOS SSCI (Clarivate Analytics) and in Scopus (Elsevier). After these two, there are another five titles in Scopus and also in ESCI (Emerging Sources Citation Index) part of WoS: Anales de documentación, BiD, Ibersid, Revista general de información y documentación, and Scire. Finally, three other titles appear only in ESCl: Cuadernos de documentación multimedia, Documentación de ciencias de la información, and Métodos de información. This recognition has been achieved in all cases since 2006, when EPI was first indexed in SSCI (WoS).

Despite this outstanding international recognition, there are still opportunities for journals to improve various aspects of their operation, as noted by Abadal (2018):

- Increase the level of professionalisation;

- Increase the number of manuscripts received;

- Incorporate new functions and features; and

- Increase dissemination activity.

These improvements, however, do not form part of the current objectives of EPI or REDC, which both enjoy editorial robustness and a higher number of original studies, a situation no doubt facilitated by their indexing in $\mathrm{SSCl}$ (WoS). This situation will continue and very probably increase in the coming years.

Finally, in view of the current situation, we agree wholeheartedly with the diagnosis by Rodríguez-Yunta \& Giménez-Toledo (2013), as we would argue not only that there is no need to create any new academic journals in Documentation, but also that mergers and co-editions should be studied to ensure a larger number of original studies and more resources (financial and human) that would help enhance journal professionalisation and features.

\section{Research projects}

Increased government funding for research has its origins in the Law for the promotion and general coordination of scientific and technical research (Law 13/86), and especially in the implementation of the first National R+D Plan (19881991), which is still in effect, although under a different name and new sub-programmes. Although there are no sub-programmes specifically for Documentation, for more than thirty years researchers in this discipline have been participating in the annual calls under the National scientific and technical research and innovation plan (current name), as current members of the Communication and Documentation subcommittee (within the area of social sciences). A similar process has been followed in relation to calls for projects issued by the European Union, which have seen an increase in Spanish participation.

In nationally funded research projects, the most active institutions have been the CSIC and Universidad Complutense

+The main obstacle to analysing the characteristics of these research projects (topics, methods, authorship, etc.) lies in the difficulties associated with accessing information on the results of the calls. In the case of EU projects, the Cordis database contains information on all projects financed with EU funds since 1990 (general description, results, publications, etc.), which can be consulted by topic, institution, etc., although it is not possible to access country-specific data. https://cordis.europa.eu/projects/en

For Spanish National Plan projects there is no similar product, and thus the only option is to search through the annual PDFs containing the project awards issued by Spain's National Research Agency, which is the managing body.

We are thus dealing with an object of study that has required researchers to invest a great deal of time in data collection. This explains why there is not an abundance of research in this area either. Apart from early studies containing only small numbers of projects (Abadal, 1994; Román; Sorli, 1994; Abellán-García; Serrano-Mascaraque; Ernica-Lafuente, 1997; Caridad-Sebastián et al., 2000) there is only one study we can refer to, by Delgado-López-Cózar, De-la-Moneda \& Torres-Salinas (2004), which analysed 168 LIS research projects funded through competitive calls at EU, national, and regional levels in the period 2000-2004. The majority of projects were associated with national calls (62\%), followed by regional government and EU calls (both 19\%). The most prominent institutions were Cindoc and Universidad Carlos III de Madrid, and the main topics were scientific communication, bibliometrics, and information technology. The analysis of national calls included not only the National Plan (51 of the 104 projects analysed) but also other funding initiatives existing at the time.

In this issue of the EPI journal, Travieso-Rodríguez \& Ríos-Hilario (2020) focus exclusively on projects granted by the National $R+D+l$ programme aimed at societal challenges for the period 2012-2018. It covers a total of 176 projects specialising in Documentation, although with a broader view of the field, as the top three areas of knowledge of the principal investigators (PIs) are Humanities, Philology, and Information Technology, while LIS is in fifth place (11\% of the total number of projects). The most active institutions have been CSIC and Universidad Complutense. Only 35\% of PIs were women and the main topics covered were information resources and information use and sociology, among other issues analysed.

One of the main limitations at this time is the absence of studies of Spanish participation in EU Documentation projects. Delgado-López-Cózar, De-la-Moneda \& Torres-Salinas (2004) did include these in their study, confirming that they represented a low proportion of the total (only $19 \%$, compared to $62 \%$ national projects). 


\section{Doctoral theses}

Doctoral theses are considered the initiation of research practice and constitute the confirmation of the research competencies of their authors. A thesis is a highly structured document resulting from academic collaboration between the doctoral candidate and thesis director undertaken in the context of a doctoral programme. These characteristics differentiate it from the other types of publications analysed above.

The Teseo database is the main instrument used to identify the theses completed at Spanish universities. This database uses the Unesco topic classification, which includes four codes directly related to the discipline that make it possible to determine an approximate figure for theses on Documentation and the growth thereof in recent years (Table 3).
Table 3. Documentation theses completed at Spanish universities

\begin{tabular}{|l|c|c|}
\hline \multicolumn{1}{|c|}{ Descriptor } & $\mathbf{1 9 8 0 - 2 0 0 0}$ & $\mathbf{2 0 0 0 - 2 0 2 0}$ \\
\hline 570102 - Automated documentation & 57 & 128 \\
\hline 570105 - Indexing languages & 20 & 58 \\
\hline 570106 - Documentation & 110 & 506 \\
\hline 570113 - Bibliometrics & 50 & 177 \\
\hline Total & 237 & 869 \\
\hline
\end{tabular}

Source: Teseo

The increase in the number of theses over the last twenty years has been considerable (around $360 \%$ ) and is in line with the total figures for the other publications mentioned above. This clearly confirms the increased productivity and dynamism of doctoral programmes in this field. It should be borne in mind, however, that the database includes both Spanish authors and foreign researchers who have been attracted to complete a doctoral programme in Spain.

Up to the year 2000, most studies of theses were essentially descriptive (Román; Sorli, 1994; Abadal, 1994; Delgado-López-Cózar, 2002; Fuentes-Pujol; González-Quesada, 2002), but since then other approaches have been included, such as the role of thesis directors (López-Yepes, 2002a, 2002b), academic approaches determined based on a director-doctoral candidate genealogy (Delgado-López-Cózar et al., 2006), or studies of participation in thesis committees (Olmeda-Gómez et al., 2009).

In this issue of EPI, González-Alcaide \& González-Teruel (2020) combine these previous focuses perfectly, as they do not limit their study exclusively to a state of the question on theses; instead, their objective is to characterise the state of LIS in Spain from the perspective of the direction of doctoral theses. To this end, they have gathered data on LIS faculty (321 professors in the 2019-20 academic year), which they relate to the 644 doctoral theses they have directed. Notable among the results is the fact that $38 \%$ of teaching and research staff (TRS) have never directed a thesis and that since their appointment $60 \%$ of permanent faculty have directed an average number of theses per year that is below the average for the area. On the other hand, they found a high concentration of theses among a small number of directors ( $8 \%$ of faculty directed $42 \%$ of theses), and a low participation of women ( 1.8 theses directed compared to 2.6 for men). They also highlight a lack of subject specialisation among thesis directors, and especially a lack of correlation between the topics of theses directed and publications in academic journals. It is thus a study that places the emphasis on the risks and imbalances observed in the analysis of thesis direction.

\section{Evaluation}

As has been shown above, the total figures for Spanish research in Documentation over the last 20 years are very positive, as this analysis confirms a quantitative increase in publications, theses, etc., a qualitative improvement in the use of research methods and techniques, and a diversification of topics and methods. In this section, we offer some observations on the progress made in recent years in light of the issues identified for previous periods.

Recalling the assessment by Williamson (1931) and applying it to the Spanish case, we find that researchers no longer work exclusively on their own (the level of co-authorship reflected in bibliometric studies is evidence of this), that there are financial resources available for research (both through national and EU programmes and due to the increase in university TRS and researcher numbers), and that there are also specialised academic journals (18 titles for Documentation, two of which are indexed in $\mathrm{SSCl}$, five in $\mathrm{ESCl}$ and seven in Scopus).

In the following points we compare the limitations noted by Abadal (1994) and Delgado-López-Cózar (2000) against the data and evidence presented here.

\section{a) Research is oriented towards dissemination}

The bibliometric studies discussed above not only reflect the diversification of topics and methods, but also reveal contributions of new knowledge (not just dissemination of existing knowledge). Evidence of this is the percentage of articles by Spanish authors cited in WoS (72\%), a noteworthy proportion if we take into account that this constitutes a large collection of documents.

\section{b) Lack of international impact}

The number of publications in international journals experienced a spectacular upturn in 2004 and has continued to increase constantly, as shown in Figure 1. While it is true that the addition of two Spanish journals to the WoS database 
has contributed to this growth, it has by no means been the decisive factor. As a result, Spanish publications currently have a much stronger presence and visibility at the international level.

\section{c) Limited financial and human resources}

Competitive calls for both EU and national research support programmes increased significantly in the early 1990 s and have remained steady (or increased) since then, with the participation a significant number of LIS researchers. Supporting this conclusion is the data on projects approved in Spain's national R+D plan, showing an increase from 51 projects in the period 2000-04 (Delgado-López-Cózar; De-la-Moneda; Torres-Salinas, 2004) to 176 in the period 2012-18 (Travieso-Rodríguez; Ríos-Hilario, 2020).

\section{d) Lack of methodological quality}

Studies conducted on research techniques and methods have revealed considerable diversification in this area, predominated by descriptive research, metric studies, and also theoretical studies. On the other hand, the best evidence for the increase in methodological quality can be found in the high number of articles in international journals, given that these publications have made it through the most demanding quality filters in the world.

Based on the above, it is our view that most of the issues affecting research in Documentation in the period 1980-2000 have been overcome. However, we have identified one aspect where improvement is still needed: the level of internationalisation. While it is true (as shown above) that the number of publications in international journals has increased, this is only one element of internationalisation, and there are other dimensions where much more progress can still be made. How can internationalisation be measured? Navas-Fernández, Abadal \& Rodrigues (2018) conducted an analysis of this question with reference to Spanish academic journals and established a range of indicators for analysis (composition of advisory boards,

Although the issues affecting research in Documentation in the period 1980-2000 have been effectively overcome, there is still one area for improvement: the level of internationalisation

language, inclusion of foreign authors, etc.) and concluded that these journals have a low level of international engagement. In the case of research, in general two basic dimensions can be identified:

- Collaboration with authors from other countries

The data provided by Clarivate InCites (Table 1) shows that $26 \%$ of publications are the product of international collaborations. Although there has been an improvement over the period 1980-2000 (rising from 14\% to 26\%) and this percentage is in fact similar to or higher than other social sciences, it must be acknowledged that there is plenty of room for improvement and that the figures should be closer to those found among the health sciences and experimental sciences.

- Participation in international projects

Another shortfall can be found in participation in competitive calls for international research funding (especially EU funding), which Delgado-López-Cózar, De-la-Moneda \& Torres-Salinas (2004) have identified as representing only $19 \%$ of the total number of projects. This percentage is substantially lower than the percentages of international publications. It is likely that the predominance of individual or small-group work constitutes something of an obstacle to success in these kinds of calls. It is therefore necessary to find synergies between research groups (and not just national groups) to submit proposals to EU calls, as it is worth remembering that participation in these calls compels researchers to associate with organisations from other countries.

In short, it is clear that the progress made in research in Documentation over the past 20 years has been notable on nearly all fronts -except for the low level of internationalisation- and that the classification of "embryonic stage" used to describe the state of the field in the last years of the 20th century (Delgado-López-Cózar, 2000) is no longer applicable.

However, there is a threat looming on the horizon. This threat is not directly related to research, but it certainly could affect its future growth. It is the declining number of students enrolled in university programmes in LIS, a situation that is affecting the recruitment of university faculty in this knowledge area (De-la-Moneda, 2018). Much of the quantitative growth in the period analysed has been due to research activity by significant numbers of TRS at universities, hired in response to the high number of enrolments in BIS programmes in the past. At this time, faculty numbers are stable (many faculty members are public employees), but their average age is advanced and a large number of retirements are expected in coming years. Since 2008, due to the budgetary restrictions imposed after the financial crisis and the low demand for teaching staff, most retiring faculty in Library and Information Science are not being replaced and it is expected that this trend will continue for several years to come. This human resource deficit is without doubt the biggest threat to the continued growth in research activity and to the achievement of the improvements outlined above.

There is a threat looming on the horizon, not directly related to research but that could nevertheless affect its growth: the declining number of students enrolled in university programmes in LIS 


\section{References}

Abadal, Ernest (1994). La documentación en España. Madrid: Cindoc; Fesabid, 200 pp. http://digital.csic.es/handle/10261/36885

Abadal, Ernest (2006). Mètodes i tècniques de recerca en biblioteconomia i documentació, Universitat de Barcelona. http://eprints.rclis.org/15722

Abadal, Ernest (2013). "La biblioteconomía y la documentación en la universidad española a principios del siglo XXI". Nuovi annali della Scuola speciale per archivisti e bibliotecari, Anno XXVII, pp. 211-228.

https://fima.ub.edu/pub/abadal/sites/abadal/files/2013-abadal-NuoviAnnali.pdf

Abadal, Ernest (2018). “¿Cómo han cambiado BiD y las revistas españolas de documentación en los últimos veinte años?". BiD: textos universitaris de biblioteconomia i documentació, n. 40.

https://doi.org/10.1344/BiD2018.40.11

Abellán-García, Antonio; Serrano-Mascaraque, Esmeralda; Ernica-Lafuente, Emilio (1997). "El estado actual de la investigación en información y documentación en España, Europa, EEUU y algunos países iberoamericanos: proyectos de investigación sobre información, documentación y biblioteconomía entre los años 1990-1996". En: I Jornadas andaluzas de documentación (Jadoc'97). Sevilla: Asociación Andaluza de Documentalistas, pp. 49-59.

Ardanuy, Jordi (2012). "Scientific collaboration in Library and Information Science viewed through the Web of Knowledge: The Spanish case". Scientometrics, v. 90, pp. 877-890.

https://doi.org/10.1007/s11192-011-0552-1

Caridad-Sebastián, Mercedes; Moreiro-González, José-Antonio; Martín-Galán, Bonifacio; Rodríguez-Mateos, David (2000). "Los proyectos universitarios de investigación en biblioteconomía y documentación: estado de la cuestión en Madrid y Cataluña”. En: Encuentro británico/español de profesores de biblioteconomía y documentación, 2000.

De-la-Moneda, Mercedes (2018). “Las cifras de la enseñanza universitaria en Documentación en España: 2016”. Anuario ThinkEPI, v. 12, pp. 15-35.

https://doi.org/10.3145/thinkepi.2018.02

Delgado-López-Cózar, Emilio (2000). “Diagnóstico de la investigación en Biblioteconomía y Documentación en España (1976-1996): estado embrionario". Revista de investigación iberoamericana en ciencia de la información y documentación, v. 1, n. 1, pp. 79-93.

http://eprints.rclis.org/13833

Delgado-López-Cózar, Emilio (2002). La investigación en Biblioteconomía y Documentación. Gijón: Trea.

Delgado-López-Cózar, Emilio; De-la-Moneda, Mercedes; Torres-Salinas, Daniel (2004). “Projectes d'investigació en Biblioteconomia i Documentació a Espanya". Anuari Socadi.

https://www.raco.cat/index.php/Bibliodoc/article/view/16667/41462

Delgado-López-Cózar, Emilio; Torres-Salinas, Daniel; Jiménez-Contreras, Evaristo; Ruiz-Pérez, Rafael (2006). “Análisis bibliométrico y de redes sociales aplicado a las tesis bibliométricas defendidas en España (1976-2002): temas, escuelas científicas y redes académicas". Revista española de documentación científica, v. 29, n. 4, pp. 493-524.

http://doi.org/10.3989/redc.2006.v29.i4.306

Faba-Pérez, Cristina; Pérez-Pulido, Margarita (2019). "Tendencias en metodología de investigación en Información y Documentación”. En: Carrillo-Durán, M. Victoria; Pérez-Pulido, Margarita (eds.). Metodologías y experiencias de investigación en comunicación e información. Cuadernos Artesanos de Comunicación, La Laguna (Tenerife).

https://doi.org/10.4185/cac163

Ferran-Ferrer, Núria; Guallar, Javier; Abadal, Ernest; Server, Adan (2017). "Research methods and techniques in Spanish library and information science journals (2012-2014)". Information research, v. 22, n. 1.

http://www.informationr.net/ir/22-1/paper741.html

Figuerola, Carlos G.; García-Marco, Francisco-Javier; Pinto, María (2017). “Mapping the evolution of library and information science (1978-2014) using topic modeling on LISA". Scientometrics, v. 112, n. 3.

https://doi.org/10.1007/s11192-017-2432-9

Fuentes-Pujol, Maria-Eulàlia; González-Quesada, Alfons (2001). “La investigación y la literatura especializada en Información y Documentación: una revisión". Scire, v. 7, n. 2.

https://dialnet.unirioja.es/servlet/articulo?codigo=290314

Fuentes-Pujol, Maria-Eulàlia; González-Quesada, Alfons (2002). “Tesis doctorales en España en información y documentación, 1976-2001". En: Morán-Suárez, M. A.; Rodríguez-López, M. C. La documentación para la investigación. Homenaje a José Antonio Martín Fuertes. León: Universidad de León, pp. 229-242 
García-Marco, Francisco-Javier; Figuerola, Carlos G.; Pinto, María (2020). “Análisis de la evolución temática de la investigación sobre Información y Documentación en español en la base de datos LISA mediante modelado temático (19782019)". Profesional de la información, v. 29, n. 4, e290427.

https://doi.org/10.3145/epi.2020.jul.27

González-Alcaide, Gregorio; González-Teruel, Aurora (2020). "Dirección de tesis doctorales como reflejo de la Biblioteconomía y Documentación académica española: actores y temas". Profesional de la información, v. 29, n. 4, e290441. https://doi.org/10.3145/epi.2020.jul.41

Guallar, Javier (2003). "Mètodes i tècniques de recerca en els articles de documentació periodística a Espanya (19972002)". BiD: textos universitaris de biblioteconomia i documentació, n. 11.

http://bid.ub.edu/11gualla.htm

Guallar, Javier; Ferran-Ferrer, Núria; Abadal, Ernest; Server, Adán (2017). "Revistas científicas españolas de información y documentación: análisis temático y metodológico". El profesional de la información, v. 26, n. 5, pp. 947-960.

https://doi.org/10.3145/epi.2017.sep.16

Järvelin, Kalervo; Vakkari, Pertti (1990). "Content analysis of research articles in library and information science". Library and information science research, v. 12, n. 4, pp. 395-421.

https://goo.gl/bH8jKf

Järvelin, Kalervo; Vakkari, Pertti (1993). "The evolution of library and information science 1965-1985: A content analysis of journal articles". Information processing \& management, v. 29, n. 1, pp. 129-144.

https://doi.org/10.1016/0306-4573(93)90028-C

Jiménez-Contreras, Evaristo (2002). “La aportación española a la producción científica internacional en biblioteconomía y documentación: balance de diez años (1992-2001)". BiD: textos universitaris de biblioteconomia i documentació, n. 9. http://bid.ub.edu/09jimen2.htm

Jiménez-Contreras, Evaristo; Delgado-López-Cózar, Emilio; Ruiz-Pérez, Rafael (2006). “Producción española en biblioteconomía y documentación con visibilidad internacional a través de Web of science (1995-2004)". El profesional de la información, v. 15, n. 5, pp. 373-383.

http://www.elprofesionaldelainformacion.com/contenidos/2006/septiembre/6.pdf

Kawalec, Anna (2013). "Research trends in library and information science based on Spanish scientific publication 2000 to 2010 ". Malaysian journal of library \& information science, v. 18, n. 2, pp. 1-13.

http://ejum.fsktm.um.edu.my/article/1370.pdf

Larivière, Vincent; Sugimoto, Cassidy R.; Cronin, Blaise (2012). "A bibliometric chronicling of library and information science's first hundred years". Journal of the American Society for Information Science and Technology, v. 63, n. 5, pp. 997-1016.

https://doi.org/10.1002/asi.22645

López-Robles, José-Ricardo; Guallar, Javier; Otegi-Olaso, José-Ramón; Gamboa-Rosales, Nadia-Karina (2019). “El profesional de la información (EPI): bibliometric and thematic analysis (2006-2017)". El profesional de la información, v. 28, n. 4, e280417.

https://doi.org/10.3145/epi.2019.jul.17

López-Yepes, José (2002a). “Focos de investigación y escuelas científicas en documentación. La experiencia de las tesis doctorales". El profesional de la información, v. 11, n. 1, pp. 46-52.

https://doi.org/10.1076/epri.11.1.46.9061

López-Yepes, José (2002b). “Focos de investigación y escuelas científicas en documentación a través de la realización y dirección de tesis doctorales: El caso del departamento de biblioteconomía y documentación de la Universidad Complutense de Madrid (1983-2001)". Documentación de las ciencias de la información, v. 25, pp. 19-54.

Navas-Fernández, Miguel; Abadal, Ernest; Rodrigues, Rosângela-Schwarz (2018). "Internationality of Spanish scholarly journals indexed in Web of Science and Scopus". Revista española de documentación científica, v. 41, n. 3. e209.

https:// doi.org/10.3989/redc.2018.3.1498

Olmeda-Gómez, Carlos; De-Moya-Anegón, Félix (2016). “Publishing trends in Library and Information Sciences across European countries and institutions". Journal of academic librarianship, v. 42, n. 1, pp. 27-37.

https://doi.org/10.1016/j.acalib.2015.10.005

Olmeda-Gómez, Carlos; Ovalle-Perandones, María-Antonia; Perianes-Rodríguez, Antonio (2017). “Co-word analysis and thematic landscapes in Spanish information science literature, 1985-2014". Scientometrics, v. 113.

https://doi.org/10.1007/s11192-017-2486-8 
Olmeda-Gómez, Carlos; Perianes-Rodríguez, Antonio; Ovalle-Perandones, María-Antonia; De-Moya-Anegón, Félix (2009). "Colegios visibles: estructuras de coparticipación en tribunales de tesis doctorales de biblioteconomía y documentación en España”. El profesional de la información, v. 18, n. 1, pp. 41-49.

https://doi.org/10.3145/epi.2009.ene.06

Pons, Amadeu (1998). “Bibliografia espanyola en Biblioteconomia i Documentació (1990-1995)". BiD: textos universitaris de biblioteconomia i documentació, n. 1.

https://www.raco.cat/index.php/BiD/article/view/16636

Ríos-Hilario, Ana-Belén (2001). “Diez años de investigación en la Revista española de documentación científica (19891999)". Revista española de documentación científica, v. 24, n. 4, pp. 433-449.

https://doi.org/10.3989/redc.2001.v24.i4.70

Ríos-Hilario, Ana-Belén; Travieso-Rodríguez, Críspulo (2013). “Estudio de la Revista española de documentación científica: análisis comparativo de los períodos 1989-1999 y 2000-2010". Revista española de documentación científica, v. 36, n. 3, e016.

https://doi.org/10.3989/redc.2013.3.990

Rodríguez-Gairín, Josep-Manuel; Somoza-Fernández, Marta; Urbano, Cristóbal (2011). “MIAR: hacia un entorno colaborativo de editores, autores y evaluadores de revistas". El profesional de la información, v. 20, n. 5, pp. 589-595.

https://doi.org/10.3145/epi.2011.sep.15

Rodríguez-Yunta, Luis; Giménez-Toledo, Elea (2013). “Fusión, coedición o reestructuración de revistas científicas en humanidades y ciencias sociales". El profesional de la información, v. 22, n. 1, pp. 36-45.

https://doi.org/10.3145/epi.2013.ene.05

Román, Adelaida; Sorli, Ángela (1994). “La Documentación en los 90. ¿¿Podemos predecir el futuro rastreando el pasado reciente de la investigación documental?". En: Terceras Jornadas españolas de documentación automatizada. Palma de Mallorca: Universitat de les Illes Balears, pp. 1171-1185.

Scholarly Publishing Indicators (2020).

http://ilia.cchs.csic.es/SPI/index.html_

SCImago (2005). "Producción española con visibilidad internacional (ISI-WOS) en biblioteconomía y documentación (I)". El profesional de la información, v. 14, n. 6, pp. 451-461.

http://www.elprofesionaldelainformacion.com/contenidos/2005/noviembre/8.pdf

SCImago (2006). “Producción española con visibilidad internacional (ISI-WOS) en biblioteconomía y documentación (II). El profesional de la información, v. 15, n. 1, pp. 34-36.

http://www.elprofesionaldelainformacion.com/contenidos/2006/enero/6.pdf

Tramullas, Jesús (2020). “Temas y métodos de investigación en Ciencia de la Información, 2000-2019: revisión bibliográfica". Profesional de la información, v. 29, n. 4. e290417.

https://doi.org/10.3145/epi.2020.jul.17

Travieso-Rodríguez, Críspulo; Ríos-Hilario, Ana (2020). “Análisis de los proyectos de investigación sobre Información y Documentación del Programa estatal de I+D+i orientada a los retos de la sociedad (2012-2018)". Profesional de la información, v. 29, n. 4, e290416.

https://doi.org/10.3145/epi.2020.jul.16

Urbano, Cristóbal; Ardanuy, Jordi (2020). “Cross-disciplinary collaboration versus coexistence in LIS serials: analysis of authorship affiliations in four European countries". Scientometrics, n. 124, pp. 575-602.

https://doi.org/10.1007/s11192-020-03471-z

Urbano, Cristóbal; Rodrigues, Rosângela-Schwarz; Somoza-Fernández, Marta; Rodríguez-Gairín, Josep-Manuel (2020). "Why are new journals created? An international analysis of Information and Documentation titles (2013-2018)". Profesional de la información, v. 29, n. 4, e290413.

https://doi.org/10.3145/epi.2020.jul.13

Williamson, Charles C. (1931). "The place of research in library service”. Library quarterly, v. 1, n. 1, pp. 1-17. https://doi.org/10.1086/612836 